\title{
Disentangling Webb: Governmental Intimidation of Defense Witnesses and Harmless Error Analysis
}

\author{
Craig Goldblatt $\dagger$
}

In the days leading up to a criminal trial, the prosecutor contacts a potential defense witness and threatens to charge her with a crime if she testifies on the defendant's behalf. The witness declines to testify, and the defendant is convicted. Such governmental intimidation of a potential defense witness violates the criminal defendant's rights to compulsory process and due process of law. ${ }^{1}$ However, this violation might not trigger a reversal of conviction. In some cases, the silenced testimony of the intimidated witness may have been wholly cumulative, and the evidence of the defendant's guilt may be overwhelming. Should an appellate court then declare that the intimidation of the potential witness was harmless error, and uphold the conviction? Under current law, the question appears open.

Some constitutional violations of a defendant's rights require the automatic reversal of any subsequent conviction, whether or not the violation contributed causally to the verdict. ${ }^{2}$ Per se reversal, however, is the "exception and not the rule." A court will generally not reverse a conviction if it deems the error "harmless"-if the error did not actually prejudice the defendant by affecting the outcome of the trial. The Supreme Court has applied the harmless error doctrine in recent years to an increasing variety of trial errors, including most constitutional violations. ${ }^{4}$ However, the boundaries of the doctrine remain ambiguous. In particular, it is unclear whether harmless error analysis applies to the government's intimidation of a potential defense witness.

$\dagger$ B.A. 1990, Georgetown University; J.D. Candidate 1993, The University of Chicago.

I Webb v Texas, 409 US 95 (1972) (per curiam).

2 See, for example, Vasquez v Hillery, 474 US 254 (1986) (racial discrimination in selection of a grand jury may not be treated as harmless); Jackson $v$ Virginia, 443 US 307 (1979) (the failure to instruct the jury on the "beyond a reasonable doubt" standard requires reversal).

${ }^{3}$ Rose v Clark, 478 US 570, 578 (1986).

- See Arizona v Fulminante, 111 S Ct 1246, 1263 (1991). 
In Webb v Texas, a 1972 per curiam opinion, the Supreme Court summarily reversed a conviction after the trial judge "gratuitously singled out" the lone defense witness for a lengthy admonition on the consequences of perjury. ${ }^{5}$ The Court reversed the conviction without analyzing the error's prejudicial effect and despite "apparently overwhelming evidence of guilt." Many lower courts have read this decision to require per se reversal in cases of governmental intimidation of a potential defense witness. However, these courts have misread Webb. A better reading suggests that $W e b b$ actually addressed the level of error necessary for summary reversal. The Court never addresses the question of whether the error may be treated as harmless. ${ }^{7}$

A number of circuit courts, citing $W e b b$, require per se reversal in cases of governmental intimidation of defense witnesses. Other circuits, citing later Supreme Court decisions that have expanded the harmless error doctrine, have apparently concluded that these cases tacitly overturn any requirement of per se reversal that might follow from $W e b b$.

In light of the broadening application of the harmless error doctrine across a wide spectrum of constitutional violations, the Supreme Court's failure to explicitly subject Webb errors to harmless error analysis might be seen as little more than an oversight. This Comment, however, will argue against such a view. Although harmless error analysis has been found applicable to an increasing variety of constitutional errors, the Court has recently reaffirmed that errors described as "structural defects" require per se reversal. ${ }^{8}$

Structural defects have two essential characteristics. First, it is extremely difficult to determine whether such errors actually prejudiced the defendant. Second, such errors affect the structural integrity of the trial in a systemic manner. This Comment will argue that governmental intimidation of a defense witness satisfies both prongs of this test. Such an error, therefore, requires per se reversal.

Section I examines the historical foundations of the harmless error doctrine, and outlines the relevant Supreme Court jurisprudence. This Section also addresses the Court's application of harmless error analysis to constitutional violations, and describes the

- Webb, 409 US at 97.

- Id at 99 (Blackmun dissenting).

7 See Section II. C.

${ }^{8}$ See Fulminante, $111 \mathrm{~S} \mathrm{Ct}$ at 1265. 
doctrine's rapid expansion in recent years. Section II discusses $W e b b$, and then examines the mixed treatment the case has received in the lower federal courts. Finally, Section III argues that the guidance set forth in recent Supreme Court cases requires the per se reversal of a subsequent conviction where the government has intimidated a defense witness.

\section{The Harmless Error Doctrine}

\section{A. Historical Overview of Harmless Error}

Under the original eighteenth-century English common law rule, when an error was committed at trial, appellate judges reversed convictions only where it seemed that the trial error caused an incorrect outcome. ${ }^{9}$ Under this approach, even where an error clearly prejudiced the defendant, a new trial would not be in order unless the appeals court concluded that the trial court reached the wrong result. ${ }^{10}$

The English courts rejected the original rule in the middle of the nineteenth century, and established the Exchequer Rule, under which no error could ever be treated as harmless. ${ }^{11}$ This rule of automatic per se reversal, which other courts speedily accepted, ${ }^{12}$ required reversals for even the most trivial errors. "New trials were ordered at the drop of a hat .... However minuscule the errors, there was heroic spraying for overkill."13

Most American courts quickly embraced the Exchequer Rule of automatic reversal, ${ }^{14}$ but almost every state legislature responded by enacting a harmless error statute designed to allow convictions to stand despite trivial errors at trial. ${ }^{13}$ Additionally, Congress enacted a harmless error statute in 1919, which provided that federal courts were not to reverse judgments because of errors 1983).

- See John Henry Wigmore, 1 Evidence § 21 at 885 nn 2-5 (Little, Brown, Tillers rev

10 Id at 884.

11 Crease v Barrett, 149 Eng Rep 1353 (Ex 1835). See Wigmore, 1 Evidence $\$ 21$ at 887. But see Roger Traynor, The Riddle of Harmless Error 4 (Ohio State, 1970) (arguing that Crease's progeny, and not Crease itself, established the Exchequer Rule).

12 Wigmore, 1 Evidence $\S 21$ at 887.

13 Traynor, The Riddle of Harmless Error at 4.

14 Wigmore, 1 Evidence $\S 21$ at 888 ; Marcus A. Kavanagh, Improvement of Administration of Criminal Justice By Exercise of Judicial Power, 11 ABA J 217, 219 (1925). See also Lester Orfield, Criminal Appeals in America 182-211 (Little, Brown, 1939).

15 See Steven H. Goldberg, Harmless Error: Constitutional Sneak Thief, $71 \mathrm{~J}$ Crim L \& Criminol 421, 422-23 (1980). Today, "[a]ll 50 [s]tates have harmless-error statutes or rules." Chapman v California, 386 US 18, 22 (1967). 
that did not affect the parties' substantial rights. ${ }^{16}$ The current federal harmless error statute ${ }^{17}$ and the Federal Rules of Criminal Procedure ${ }^{18}$ adopt a similar approach..$^{19}$

The federal harmless error statute does not establish any standard by which a court may determine whether an error affected a defendant's substantial rights. The statute's legislative history sheds little additional light, except to suggest that the statute intended to rule out purely technical violations as a basis for a new trial. ${ }^{20}$

In Kotteakos v United States, the Supreme Court adopted a "reasonable possibility" standard, under which the Court would not treat an error as harmless if it was reasonably possible that it "had [a] substantial influence" on the outcome of the trial. ${ }^{21}$ If "one is left in grave doubt, the conviction cannot stand." Kotteakos Court made clear that appellate courts were not simply to determine whether they thought it likely that the resulting verdict was correct, as under the original English rule. Rather, a court should allow a conviction to stand only when it is certain that the error either did not affect the jury at all, or had only a "very slight effect."23

Because Kotteakos did not involve constitutional error, the Court explicitly reserved the question of whether harmless error applied in such cases. The Court noted, however, that a harmless

16 Act of Feb 26, 1919, 48 USC $\S 269$ (1988) ("On the hearing of any appeal, certiorari, writ of error, or motion for a new trial, in any case, civil or criminal, the court shall give judgment after an examination of the entire record before the court, without regard to technical errors, defects, or exceptions which do not affect the substantial rights of the parties.").

1228 USC $\S 2111$ (1989) ("On the hearing of any appeal or writ of certiorari in any case, the court shall give judgment after an examination of the record without regard to errors or defects which do not affect the substantial rights of the parties.").

18 FRCrP 52(a) ("Any error, defect, irregularity or variance which does not affect substantial rights shall be disregarded.").

18 See also FRE 103(a) ("Error may not be predicated upon a ruling which admits or excludes evidence unless a substantial right of the party is affected ...").

${ }^{20}$ See Traynor, The Riddle of Harmless Error at 42 (cited in note 11). See also Orfield, Criminal Appeals in America at 196 (cited in note 14). While one might think the language contemplates a distinction between procedural errors, which will not require reversal, and substantive ones that will, there does not appear to be anything in the legislative history to support such a reading. Compare Henry $v$ Mississippi, 379 US 443 (1965) (distinguishing between substantive and procedural state grounds in federal habeas proceedings).

${ }^{21} 328$ US 750, 765 (1946). See Stephen A. Saltzburg, The Harm of Harmless Error, 59

U Va L Rev 988, 1009 (1973).

${ }^{22} 328$ US at 765 .

${ }^{23}$ Id at 764 . 
error analysis might not apply "where the departure is from a constitutional norm."24

\section{B. Harmless Constitutional Error}

In Chapman $v$ California the Court concluded that harmless error analysis could apply to constitutional violations. ${ }^{25}$ The Court recognized that the text of the federal harmless error statute does not distinguish between constitutional and non-constitutional errors. ${ }^{26}$ The Court further found that there may be some constitutional errors so "insignificant that they may, consistent with the Federal Constitution, be deemed harmless, not requiring the automatic reversal of the conviction."27

24 Id at 764-65 (footnote omitted).

${ }^{25} 386$ US 18 (1967). Four years earlier, in Fahy v Connecticut, 375 US 85 (1963), the Court expressly chose not to decide whether harmless error analysis could apply to constitutional errors, leaving the issue to the Chapman Court to resolve. Note the parallel in that Chapman was decided at a time when the Court had been rapidly expanding the constitutional protections afforded criminal defendants, see, for example, Fay v Noia, 372 US 391 (1963) (holding that habeas corpus relief is available to criminal defendants whose convictions were based on coerced confessions), but at the same time was working to limit some of the broader effects of those same decisions. See Linkletter $v$ Walker, 381 US 618 (1965) (limiting the retroactive application of new constitutional doctrine). See also David A. Strauss, Discriminatory Intent and the Taming of Brown, 56 U Chi L Rev 935, 955 (1989), citing Benjamin N. Cardozo, The Nature of the Judicial Process 51 (Yale, 1921), discussing a "systematic process in the law, a process of taming. Great principles are announced in a form that is both vague and potentially far-reaching. Pressure then develops to tame them by reducing them to something that is both apparently more clear and more objective, and apparently less threatening to established institutions."

${ }^{26} 386$ US at $22 ; 28$ USC $\$ 2111$.

${ }^{27} 386$ US at 22. While a full analysis of the issue is beyond the scope of this Comment, note that the application of the harmless error rule to constitutional errors raises a question for the "originalist" approach to constitutional interpretation. In 1791, the orthodox English rule was applied almost universally. Thus, the substantive guarantees of the Bill of Rights were written against a background that assumed that the violation of these rights would not lead to a new trial unless the violation led the trial court to reach an incorrect result.

By 1868, the year that the Fourteenth Amendment was ratified, the Exchequer rule was widely in effect. Thus, when the framers of the Fourteenth Amendment wrote that no state may "deprive any person of life, liberty, or property, without due process of law," the contemporaneous understanding of due process was that any trial error, regardless of how trivial, required an automatic reversal and a new trial. Therefore, the application of the doctrine of originalism to harmless error would require a new trial when a constitutional error is committed in a state criminal trial, but the reversal of a conviction in a federal trial only where it appears that the wrong result had been reached. See generally Antonin Scalia, Originalism: The Lesser Evil, 57 U Cinn L Rev 849 (1989); Robert H. Bork, The Tempting of America: The Political Seduction of the Law (Free Press, 1990). These absurd and inequitable results produced by an originalist approach to harmless error perhaps explain why the argument for the original understanding of harmless error has not been advanced. For a related claim in the free expression context, see Cass R. Sunstein, Free Speech Now, 59 U Chi L Rev 255, 305 n 155 (1992). 
Nonetheless, the Chapman Court formulated a special standard of review for constitutional errors. Instead of the "reasonable possibility" test of Kotteakos, the Court said that constitutional error "casts on someone other than the person prejudiced by it a burden to show that it was harmless."28 Before a court finds a constitutional error harmless, the government must prove, beyond a reasonable doubt, that the error caused no harm. ${ }^{29}$ If the government does not meet this burden, the reviewing court must reverse and order a new trial..$^{30}$

The Chapman Court did not hold that harmless error analysis applies to all constitutional errors. To the contrary, the Court noted that "there are some constitutional rights so basic to a fair trial that their infraction can never be treated as harmless error." 31 In a footnote, the Court indicated that admission of a coerced confession, the denial of the right to counsel, and the denial of the right to an impartial judge are illustrative of the sorts of errors that require per se reversal of any subsequent conviction. ${ }^{32}$

Although commentators in the immediate wake of Chapman generally thought that most constitutional errors would remain grounds for per se reversal, ${ }^{33}$ the Supreme Court soon applied harmless error analysis to a wide variety of constitutional violations. For example, in the years immediately following Chapman, the Court applied harmless error analysis to the denial of the right to counsel at a preliminary hearing, ${ }^{34}$ to the admission of evidence obtained in violation of the Fourth Amendment, ${ }^{35}$ to the admission

28 Chapman, 386 US at 24.

29 Id.

30 The meaning of the "beyond a reasonable doubt" standard was elaborated in Harrington $v$ California, 395 US 250, 254 (1969), where the Court indicated that overwhelming independent evidence of guilt can support a finding of harmlessness. The Court similarly relied on independent untainted evidence of guilt to support a determination of harmlessness in Milton $v$ Wainwright, 407 US 371 (1972). See generally Martha A. Field, Assessing the Harmlessness of Federal Constitutional Error-A Process in Need of a Rationale, 125 U Pa L Rev 15 (1976); Carella v California, 491 US 263, 267-73 (1989) (Scalia concurring).

32 Chapman, 386 US at 23.

32 Id at $23 \mathrm{n} 8$.

s3 Phillip J. Mause, Harmless Constitutional Error: The Implications of Chapman v. California, 53 Minn L Rev 519, 557 (1969) (arguing that Chapman creates a "general rule of automatic reversal ... [ [with] certain exceptions"); Traynor, The Riddle of Harmless Error at 43 (cited in note 11) ("The Chapman test itself comes close to automatic reversal."); Note, Harmless Constitutional Error, 20 Stan L Rev 83, 98 (1967) ("the Chapman harmless-error rule should apply only to those few constitutional errors which remain outside the guilt-determination spectrum of rights").

34 Coleman v Alabama, 399 US 1 (1970).

ss Bumper $v$ North Carolina, 391 US 543 (1968); Chambers v Maroney, 399 US 42 (1970). 
of a confession in violation of the Sixth Amendment's Counsel Clause,$^{36}$ and to the admission of an out-of-court statement of a non-testifying co-defendant in violation of the Confrontation Clause. ${ }^{37}$

Since Chapman, constitutional trial errors that require per se reversal have become "the exception and not the rule." Court has emphasized that "the Constitution entitles a criminal defendant to a fair trial, not a perfect one."39 While there remain some errors that still require automatic reversal, "if the defendant had counsel and was tried by an impartial adjudicator, there is a strong presumption that any other errors that may have occurred are subject to harmless-error analysis." 40 Applying this rationale, the Court has recently subjected an exhaustive list of trial court errors to harmless error analysis. ${ }^{41}$

A discrete class of errors, however-those creating structural defects in the trial-still requires reversal "without regard to the evidence in the particular case." ${ }^{42}$ While the case law that defines this class appears somewhat contradictory and confusing, the Supreme Court fashioned a standard of sorts in Arizona $v$ Fulminante. ${ }^{43}$

${ }^{36}$ Milton $v$ Wainwright, 407 US 371 (1972).

${ }^{37}$ Brown $v$ United States, 411 US 223 (1973).

ss Rose v Clark, 478 US 570, 578 (1986).

3. Delaware v Van Arsdall, 475 US 673, 681 (1986). See also United States v Hasting, 461 US 499, 508-09 (1983) ("there can be no such thing as an error-free, perfect trial, and [] the Constitution does not guarantee such a trial").

${ }^{10}$ Rose v Clark, 478 US at 579.

41 See Clemons v Mississippi, 494 US 738, 753 (1990) (overbroad jury instructions in capital sentencing); Carella v California, 491 US 263, 266-67 (1989) (per curiam) (erroneously directing jury on conclusive presumption, in violation of due process); Satterwhite $v$ Texas, 486 US 249, 258 (1988) (admission of evidence in violation of counsel clause during capital sentencing); Pope v Illinois, 481 US 497, 501-02 (1987) (jury instruction that misstated the elements of the offense); Rose $v$ Clark, 478 US at 579-80 (jury instruction that contained an erroneous rebuttable presumption); Crane v Kentucky, 476 US 683, 691 (1986) (erroneous exclusion of defendant's testimony regarding the circumstances surrounding his confession); Delaware $v$ Van Arsdall, 475 US 673, 680, 684 (1986) (restriction on defense counsel's cross-examination in violation of confrontation clause); Rushen v Spain, 464 US $114,118-20$ (1983) (defendant denied right to attend trial); United States $v$ Hasting, 461 US 499,512 (1983) (prosecution's comment on defendant's silence at trial, in violation of selfincrimination clause); Hopper $v$ Evans, 456 US 605, 613-14 (1982) (statute forbidding a lesser-included-offense instruction in a capital case, violating due process clause); Kentucky $v$ Whorton 441 US 786, 791 (1979) (failure to instruct the jury on the presumption of innocence); Moore v Illinois, 434 US 220, 232 (1977) (admission of identification evidence, in violation of right to counsel).

42 Rose v Clark, 478 US at 577.

$4311 \mathrm{~S}$ Ct 1246 (1991). 


\section{A Standard for Per Se Reversal: Arizona v Fulminante}

Before Fulminante, the Court had made almost no effort to draw an intelligible line between those errors that may be treated as harmless, and those that require per se reversal. For example, the case law indicates that denying a defendant the right to a public trial requires per se reversal, ${ }^{44}$ while the denial of a defendant's right to be present at her trial does not. ${ }^{45}$ Failure to instruct the jury on the beyond a reasonable doubt standard requires per se reversal, ${ }^{48}$ while failure to instruct the jury on the presumption of innocence does not. ${ }^{47}$

In the face of this confusion, the Court attempted to draw a clear boundary in Arizona $v$ Fulminante. ${ }^{48}$ The Court there removed coerced confessions from the list of errors requiring per se reversal, and attempted to clarify the distinction between such errors and those subject to harmless error analysis.

The Fulminante decision overturned a number of precedents that had either held or suggested that coerced confessions could not constitute harmless error. ${ }^{49}$ However, the rationale of the badly fractured Court's decision is generally consistent with the Court's broader approach to distinguishing errors subject to harmless error analysis from those requiring per se reversal. The Court addressed itself to the footnote in Chapman that endorses per se reversal for: (1) the denial of the right to counsel; (2) the denial of the right to an impartial judge; and (3) coerced confessions. The Court noted that the admission of an involuntary confession-a classic trial error-differs markedly from the other two constitutional violations referred to in the Chapman footnote. ${ }^{50}$ The entire conduct of the trial from beginning to end is obviously affected by the absence of defense counsel or the presence of a biased judge. ${ }^{51}$

14 Waller $v$ Georgia, 467 US 39 (1984).

15 Rushen, 464 US at 117-18 \& $\mathrm{n} 2$.

t8 Jackson v Virginia, 443 US 307 (1979).

47 Whorton, 441 US at 791.

48111 S Ct 1246 (1991).

${ }^{4}$ See Payne v Arkansas, 356 US 560 (1958); Kotteakos v United States, 328 US 750, $765 \mathrm{n} 19$ (1946) ("Thus, when forced confessions have been received, reversals have followed although on other evidence guilt might be taken to be clear."). For an extensive discussion of the precedents that Fulminante overturned, see Fulminante, $111 \mathrm{~S} \mathrm{Ct}$ at 1253-54 (White dissenting). See also Tom Stacy and Kim Dayton, Rethinking Harmless Constitutional Error, 88 Colum L Rev 79, 87 (1988) (writing just four years ago that "[a]ll members of the Court appear to agree that violations of the right [] ... against coerced confessions can never be considered harmless").

so Fulminante, $111 \mathrm{~S}$ ' $\mathrm{Ct}$ at $1264-65$.

61 Id at 1265. 
The admission of a coerced confession, however, does not similarly affect the structure of the trial. Instead, it resembles other forms of illegally obtained evidence, ${ }^{52}$ because an appellate court can review the correctly admitted evidence against the defendant and determine whether the constitutional error was harmless beyond a reasonable doubt. ${ }^{53}$ The Court concluded, therefore, that errors creating a defect in the structure or framework of the trial require per se reversal, while discrete errors during the trial may be subject to harmless error analysis. ${ }^{54}$

\section{Webb and the Right to Present a Defense}

Although extensive case law and literature deal with harmless error analysis, it remains unclear whether governmental intimidation of a potential defense witness calls for per se reversal or may be subject to harmless error analysis. This Section first examines the constitutional right to present a defense, then addresses Webb $v$ Texas. In that case, the Supreme Court held that governmental intimidation of a potential defense witness violated the due process right to present a defense. This Section then examines the conflicting ways in which the lower federal courts have treated $W e b b$ errors.

A. The Compulsory Process Clause and the Right to Present a Defense

The Constitution guarantees a criminal defendant's right to offer the testimony of witnesses and to otherwise put on a defense. This right is sometimes conceived of as stemming from the Fifth and Fourteenth Amendments' guarantees of due process. ${ }^{55}$ Alternatively, a foundation for this right may be found in the Sixth Amendment's explicit guarantee of compulsory process for obtaining witnesses. ${ }^{56}$ However the textual source is understood, all agree that the Constitution provides a criminal defendant with the

s2 Id.

ss Id. See also Charles J. Ogletree, Jr., Arizona v. Fulminante: The Harm of Applying Harmless Error to Coerced Confessions, 105 Harv L Rev 152 (1991).

s4 $111 \mathrm{~S}$ Ct at 1265.

ss The Fifth Amendment provides that "[n]o person shall . . . be deprived of life, liberty, or property, without due process of law." US Const, Amend V. The Fourteenth Amendment provides a similar guarantee against the states, declaring that "nor shall any State deprive any person of life, liberty, or property, without due process of law." US Const, Amend XIV, § 1 .

so "In all criminal prosecutions, the accused shall enjoy the right . . . to have compulsory process for obtaining witnesses in his favor." US Const, Amend VI. 
right to put on a defense. "The Constitution guarantees a fair trial through the Due Process Clauses, but it defines the basic elements of a fair trial largely through the several provisions of the Sixth Amendment . . . .".57

The Supreme Court explained the scope of this right in Washington $v$ Texas. ${ }^{58}$ There, the Court confronted a state law that declared inadmissible any testimony introduced by one co-defendant to exculpate another co-defendant. In striking down the law as a violation of the Compulsory Process Clause, the Court found that:

The right to offer the testimony of witnesses, and to compel their attendance, if necessary, is in plain terms the right to present a defense, the right to present the defendant's version of the facts as well as the prosecution's to the jury so it may decide where the truth lies. Just as an accused has the right to confront the prosecution's witnesses for the purpose of challenging their testimony, he has the right to present his own witnesses to establish a defense. This right is a fundamental element of due process of law..$^{59}$

The Court thus recognized the constitutional right of a criminal defendant to call witnesses on his behalf, even in a state court proceeding. ${ }^{.0}$

\section{B. Webb $v$ Texas}

The Court again confronted the due process right to present a defense in Webb $v$ Texas. $^{81}$ The Court there found that a trial judge's intimidation of a defense witness, causing the witness to refuse to testify, violated the defendant's right to put on a defense.

Alfred Webb was charged in the Criminal District Court of Dallas County, Texas, with burglarizing the Kent Lumber Company. After the prosecution rested its case, Webb called his lone defense witness, Leslie Max Mills, who had a prior criminal record

s7 Strickland v Washington, 466 US 668, 684-85 (1984).

s8 388 US 14 (1967).

Bo Id at 19.

${ }^{80}$ See also Chambers v Mississippi, 410 US 284, 302 (1973) ("Few rights are more fundamental than that of an accused to present witnesses in his own defense."). For further discussion of the right to compulsory process and the right to present a defense see generally Robert Clinton, The Right to Present a Defense: An Emergent Constitutional Guarantee in Criminal Trials, 9 Ind L Rev 713 (1976); Peter Westen, The Compulsory Process Clause, 73 Mich L Rev 71 (1974); Alfredo Garcia, The Sixth Amendment in Modern American Jurisprudence: A Critical Perspective ch 3 (Greenwood, 1992).

61 409 US 95 (1972). 
and was then serving a prison sentence. When the defense called Mills, the trial court judge admonished the witness:

Now you have been called down as a witness in this case by the Defendant. It is the Court's duty to inform you that you don't have to testify, that anything you say can and will be used against you. If you take the witness stand and lie under oath, the Court will personally see that your case goes to the grand jury and you will be indicted for perjury and the liklihood [sic] is that you would get convicted of perjury and that it would be stacked onto what you have already got, so that is the matter you have got to make up your mind on. If you get on the witness stand and lie, it is probably going to mean several years and at least more time that you are going to have to serve. It will also be held against you in the penitentiary when you're up for parole and the Court wants you to thoroughly understand the chances you're taking by getting on that witness stand under oath. You may tell the truth and if you do, that is all right, but if you lie you can get into real trouble. The court wants you to know that. You don't owe anybody anything to testify and it must be done freely and voluntarily and with the thorough understanding that you know the hazard you are taking. ${ }^{62}$

The defendant's counsel objected to the judge's comments, and indicated that he was still going to call the witness. To this, the judge responded "[c]ounsel, you can state the facts, nobody is going to dispute it. Let him decline to testify." No Not surprisingly, the witness then refused to testify and was excused by the court.

The court denied Webb's motion for a mistrial and the jury convicted Webb. The Texas Court of Criminal Appeals affirmed the judgment, despite Webb's argument that the trial court had denied him his right to present a witness by "threatening and harassing" the witness. ${ }^{64}$ While the state appellate court criticized the judge's admonition, it did not believe that the judge's remarks had actually prejudiced the defendant. ${ }^{68}$

The Supreme Court summarily reversed Webb's conviction. ${ }^{66}$ The Court found the trial judge's lengthy warning directed to the

\footnotetext{
-2 Id at 95-96.

${ }^{63}$ Id at 96.

o4 Webb v Texas, 480 SW2d 398, 401 (Tex Crim App 1972).

ss Id.

Be Webb, 409 US at 95.
} 
single defense witness gratuitous, and noted that the trial judge may have exaggerated the extent of his powers. ${ }^{67}$ The Court concluded that "the unnecessarily strong terms used by the judge could well have exerted such duress on the witness' mind as to preclude him from making a free and voluntary choice whether or not to testify."

Citing Washington $v$ Texas, the Court inferred that the right to offer the testimony of witnesses and to compel their attendance is "in plain terms, the right to present a defense." cluded that "the judge's threatening remarks, directed only at the single witness for the defense, effectively drove that witness off the stand, and thus deprived the petitioner of due process of law under the Fourteenth Amendment." It It therefore reversed the conviction. ${ }^{71}$

Justice Blackmun, joined by Justice Rehnquist, dissented. While disapproving of the trial judge's improper conduct, Blackmun argued that the showing of error failed "to demonstrate the depth of prejudice that requires a summary reversal." $72 \mathrm{He}$ further noted that there was "apparently overwhelming evidence of guilt," offset only by a bare allegation of prejudice. ${ }^{73}$ Thus, he "would remit the petitioner to the relief available to him by way of a postconviction proceeding with a full evidentiary hearing." "74

${ }^{67}$ Id at $97-98$.

68 Id at 98.

Id, quoting Washington, 388 US at 19.

70 Id.

${ }^{21}$ On extension of the right to present a defense since Webb, see Davis $v$ Alaska, 415 US 308 (1974); Crane v Kentucky, 476 US 683 (1986); Clinton, 9 Ind L Rev at 713 (cited in note 60 ).

72 Webb, 409 US at 99 (Blackmun dissenting).

73 Id (footnote omitted).

74 Id. The court announced a limitation on the right to present a defense in United States $v$ Valenzuela-Bernal, 458 US 858 (1982), where a defendant was charged with transporting three illegal aliens into the country. When the aliens were deported, the defendant moved that his indictment be dismissed on the grounds that the deportation violated his right to compulsory due process. The Court rejected his claim, relying on the text of the Sixth Amendment, which guarantees a defendant the right to "compulsory process for obtaining witnesses in his favor." Id at 867, quoting US Const, Amend VI (emphasis added).

According to Valenzuela, the right to compulsory process is not violated unless a plausible showing is made that the testimony of the potential witness would have been "both material and favorable to defense." Id. But note that Valenzuela is not a harmless error case. The Court did not say that deporting these potential witnesses was harmless constitutional error. Instead, it found no substantive constitutional violation.

This holding, of course, does not reach cases of Webb-type error where the government is not lawfully deporting illegal aliens but is intimidating witnesses. Further, even if it did, there would remain the question of whether harmless error analysis would apply to the in- 


\section{Is Webb a Harmless Error Case?}

Many lower courts have read Webb to establish a rule of per se reversal for governmental intimidation of defense witnesses. Under this view, Justice Blackmun's dissent, emphasizing the independent evidence of guilt and the absence of a showing of prejudice, is seen as a call, rejected by the majority, to engage in harmless error analysis in this context.

There exists, however, an alternative, perhaps more sensible, reading of the case. Since the $W e b b$ majority summarily reversed the conviction below, Justice Blackmun's argument that there had not been a sufficient showing of prejudice could well have been directed toward the Court's decision to summarily reverse the conviction, rather than an argument that the error should be treated as harmless. Justice Blackmun, in this view, was contending only that the violation of the defendant's rights was not so egregious as to justify summary reversal, that is, reversal without briefs and argument. If so, $W e b b$ has nothing to do with harmless error doctrine at all. The fact that the majority decision makes reference to neither harmless error analysis nor per se reversal, and fails to cite Chapman, bolsters this argument. Were this in fact a case about harmless error, such omissions would be extremely difficult to explain.

\section{Webb Error in the Lower Federal Courts}

The Third, ${ }^{78}$ Sixth, ${ }^{76}$ and Eleventh Circuits, ${ }^{77}$ as well as a district court in the Ninth Circuit, ${ }^{78}$ have applied a rule of per se reversal to government intimidation of defense witnesses. The Second, ${ }^{79}$ Fifth, ${ }^{80}$ Seventh ${ }^{81}$ and Eighth Circuits ${ }^{82}$ reject this reading of $W e b b$, and hold that harmless error analysis applies.

timidation of witnesses whose testimony is favorable to the defendant but merely repeats testimony already before the jury.

${ }^{75}$ United States $v$ Morrison, 535 F2d 223 (3d Cir 1976).

76 United States v Thomas, 488 F2d 334 (6th Cir 1973) (per curiam).

77 Demps v Wainwright, 805 F2d 1426 (11th Cir 1986) (per curiam).

78 Berg v Morris, 483 F Supp 179 (E D Cal 1980).

70 United States v Pinto, 850 F2d 927 (2d Cir 1988).

so United States $v$ Weddell, 800 F2d 1404 (5th Cir 1986).

*Diggs $v$ Richards, 1992 US App LEXIS 4664, *4-5 (7th Cir) (unpublished order).

s2 Ray v United States, 588 F2d 601 (8th Cir 1978); Thomas v Wyrick, 687 F2d 235 (8th Cir 1982); Peeler $v$ Wyrick, 734 F2d 378 (8th Cir 1984). 
1. Rule of per se reversal.

The Third Circuit's position is typical of the cases that read $W e b b$ to require per se reversal. In United States $v$ Morrison, ${ }^{83}$ the prosecutor interviewed a prospective defense witness in an extremely intimidating manner, and warned her repeatedly that she might be charged with perjury if she testified falsely for the defendant. ${ }^{84}$ Although the district court judge denied a motion for a mistrial because the prosecutor's actions "did not cause any substantial prejudice," Supreme Court decision in Webb v Texas stands directly in the way of the District Court's conclusion and must control this case." " "[W]here the Government has prevented the defendant's witness from testifying freely before the jury, it cannot be held that the jury would not have believed the testimony or that the error is harmless." "8z

The judge intimidated the defense witness in Webb; in Morrison, the prosecutor intimidated the witness. The court held that $W e b b$ nonetheless applied, noting that a prosecutor is "a figure somewhat lower in the hierarchy than the trial judge but nonetheless the symbol of the Government's power to prosecute offenders."

2. Application of harmless error analysis.

Four federal circuits have applied harmless error analysis to governmental intimidation of defense witnesses. In a case in the Eighth Circuit, Ray $v$ United States, ${ }^{89}$ the defense alleged that FBI agents coerced a co-defendant into not testifying at the defendant's trial. While the Court did not cite Webb, it noted that "[p]rosecutorial misconduct ... may result in a deprivation of fundamental due process." "90 Nonetheless, it affirmed the district court's conviction, finding that the error caused no harm. "In such cases, the standard to be applied in determining whether a new trial should be granted is whether there is any reasonable likelihood that the new evidence could have affected the judgment of

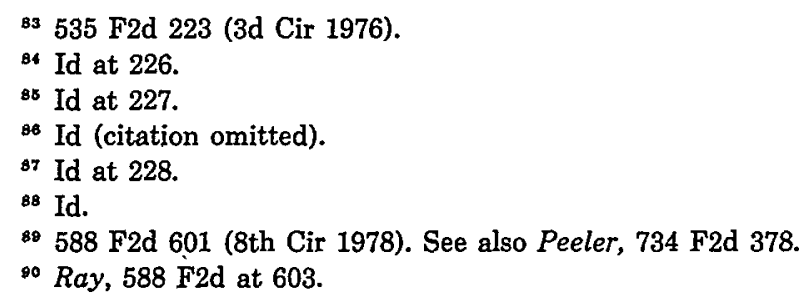


the jury." "91 The court found that there was not. The Second and Seventh Circuits take the same approach, applying harmless error in this context. ${ }^{22}$

While the Fifth Circuit had originally applied a rule of per se reversal to $W e b b$ violations, ${ }^{\text {s3 }}$ it has since found that such errors may be treated as harmless. The court explained this reversal in United States $v$ Weddell, where it found that "[r]ecent decisions of the Supreme Court lead us to conclude that a conviction may not be overturned under a per se reversal rule in cases involving constitutional due process violations of the kind in issue."94 Thus, because the "Constitution entitles a defendant to a fair trial, not a perfect one"15 the court found that Webb errors may be treated as harmless.

\section{Governmental Intimidation of Defense Witnesses As Requiring Per Se Reversal of a Subsequent Conviction}

Under current law, the question of whether governmental intimidation of potential defense witnesses requires the per se reversal of any subsequent conviction appears open. A cursory examination of the recent Supreme Court harmless error decisions might lead one to believe that harmless error analysis applies in this context. This Comment argues, however, that the Court's harmless error jurisprudence requires per se reversal. It is argued that the harmless error doctrine that emerges from Arizona $v$ Fulminante dictates the application of the following two-pronged test. A rule of per se reversal applies when (1) the error is such that a court cannot possibly determine whether it was harmless; or (2) the error impugns the structural integrity of the trial. Because governmental intimidation satisfies both prongs of this test, this constitutional error requires the per se reversal of any subsequent conviction.

After Fulminante, the governing distinction is between trial errors and structural errors. Trial errors may be treated as harm-

"Id.

92 Pinto, 850 F2d at 933 ("Recent cases have reviewed allegations of prosecutorial overreaching under the 'harmless error' standard."); Diggs, 1992 US App LEXIS 4664, *4-5 (applying harmless error to Webb error).

is United States v Hammond, 598 F2d 1008, 1013 (5th Cir 1979); United States v Goodwin, 625 F2d 693, 703 (5th Cir 1980).

94 800 F2d at 1410, (emphasis in original) citing Delaware v Van Arsdall, 475 US 570 (1986). For an examination of why such reliance is misplaced, see notes 106-109 and accompanying text (arguing that Van Arsdall supports the contention that Webb error may not be treated as harmless).

95 Weddell, 800 F2d 1410, citing United States v Hasting, 461 US 499, 508-09 (1983). 
less, while structural errors require per se reversal. ${ }^{96}$ Fulminante suggests a distinction between trial errors, which occur in the presentation of evidence to the jury, and "structural defects in the constitution of the trial mechanism." present special problems because they require "unguided speculation" ${ }^{\prime 98}$ as to the outcome of the trial in the absence of such errors, or because they fundamentally distort the trial process itself. As the Fulminante Court stated, per se reversal is considered appropriate where the error "affect[s] the framework within which the trial proceeds, rather than simply an error in the trial process itself."99

A. The First Prong: Difficulty Determining Whether the Error Was Harmless

As Professor Ogletree has noted, a "trial error seems to be one for which we can sometimes know for sure whether it has caused inaccuracy in a trial outcome, and a structural error seems to be one for which we can never know with any certainty." 100 In Fulminante, the constitutional error at issue was not the police coercion that generated the confession but the introduction of the coerced confession into evidence at trial. ${ }^{101}$ The Fulminante Court held that appellate courts are permitted to treat this error as harmless, since the required analysis parallels that which occurs whenever otherwise inadmissible evidence is introduced at trial. The appellate court should simply look at the trial court record, put the evidence that was inappropriately admitted to one side, and determine whether this constitutional error was harmless beyond a reasonable doubt. ${ }^{102}$

This reasoning makes sense of the Court's distinction between the introduction of a coerced confession on one hand, and the denial of the rights to counsel and an impartial trial judge on the other. Where a defendant is denied the right to counsel, imagining

${ }^{96}$ But see notes 44-47 and accompanying text. The extent to which these earlier, apparently irreconcilable cases survive Fulminante is, at present, unclear.

${ }^{97}$ Fulminante, $111 \mathrm{~S} \mathrm{Ct}$ at 1265. But see Ogletree, $105 \mathrm{Harv} \mathrm{L}$ Rev at 164 (cited in note 53) ("Chief Justice Rehnquist's distinction between trial and structural errors is ultimately unpersuasive.").

s8 Holloway $v$ Arkansas, 435 US 475, 491 (1978).

s $111 \mathrm{~S}$ Ct at 1265.

100 Ogletree, 105 Harv L Rev at 162 (cited in note 53).

101 According to five justices, the judge mistakenly ruled the confession was not coerced. $111 \mathrm{~S}$ Ct at 1252.

102 Id at 1265. 
the outcome of the trial had the defendant been represented by an attorney becomes an exercise in "unguided speculation," 103 because there is no complete, untainted body of evidence upon which the court may rely. Conversely, where a court erroneously admits a coerced confession, the appellate court has a complete body of "untainted" evidence to scrutinize, and can more likely determine the effect that the error had on the jury.

Young $v$ Vuitton et Fils S.A. ${ }^{104}$ made a similar point. The error there involved the appointment of a prosecutor with a financial interest in the outcome of the case. The Court found the error so woven into the fabric of the trial that harmless error analysis could not apply. Because it would be impossible to look at the record, sort out the constitutional error, and determine what the trial would have looked like had the error not been committed, the application of harmless error analysis was found inapposite. Rather, such analysis is "best suited ... where information is available that makes it possible to gauge the effect of a decision on the trial as a whole."105

Governmental intimidation of a defense witness should be seen as requiring per se reversal for similar reasons. Where a defense witness has been intimidated and has refused to testify, a hole exists in the record. The erroneous exclusion of evidence, therefore, differs from erroneous admission because erroneous exclusion denies the appellate court a complete body of "untainted" evidence to examine in determining whether the error was harmless. The appeals court will not know what the intimidated witness would have said. Even where a proffer of testimony has been made, one can never be certain what the witness's demeanor may have been and how the jury would have reacted to the testimony. The existence of a simple proffer of testimony can never convey to an appellate judge the way in which a witness would comport herself, the words she would use, or how convincing she would appear to the jury. In this regard, measuring the harm caused by the error calls for the same "unguided speculation" as in the case of a biased judge or lack of defense counsel.

10 Holloway, 435 US at $490-91$.

104 481 US 787 (1987).

105 Id at 814. This same analysis was applied in Holloway, 435 US at 490-91, where the Court concluded that requiring the same attorney to represent two defendants with conflicting interests required per se reversal. Accord Gray v Mississippi, 481 US 648, 665 (1987) ("The nature of the jury selection process defies any attempt to establish that an erroneous [] exclusion of a juror is harmless."). 
1. Where the absence of testimony has been treated as harmless: the paradoxical argument for per se reversal.

On two occasions, the Supreme Court has applied harmless error analysis to cases where, because of the constitutional error, the trial court record was left incomplete. While at first blush the results in these cases might appear to cut decisively against the contention that the incomplete record left by governmental intimidation of a defense witness requires per se reversal, this is not the case. In fact, paradoxically, these cases argue strongly that per se reversal is required when a witness for the defendant has not testified.

In Delaware $v$ Van Arsdall, ${ }^{106}$ a murder prosecution, the prosecutor entered into an agreement with one of the state's witnesses. In exchange for the witness's testimony, the prosecutor agreed to drop an unrelated criminal charge against the witness. During cross-examination of this witness, the Delaware trial court prevented defense counsel from questioning the witness about this agreement, thereby impairing the defense's ability to impeach the witness. This violated the defendant's Sixth Amendment right to effective cross-examination. ${ }^{107}$

Nonetheless, the Court applied a harmless error analysis, emphasizing that an appellate court should determine whether the jury's determination would have been affected had the damaging potential of the cross-examination been fully realized. ${ }^{108}$ The reviewing court in this case should assume that the testimony of the prosecution's witness had been thoroughly discredited and wholly disregarded by the jury. It should then figure out whether the jury, even without this testimony, would have come to the same conclusion. ${ }^{109}$

In this respect, the harmless error analysis does not involve engaging in the "unguided speculation" of filling in gaps in the record by guessing how the jury would have reacted to cross-examination. Instead, it entails the traditional harmless error exercise of disregarding part of the record, and weighing the rest. The only difference is that here, the evidence being disregarded is the testimony of the witness whom the defendant was unable to cross-examine, not evidence that was itself erroneously admitted into evidence.

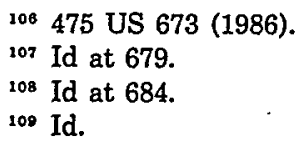


The second case where the Court found harmless error analysis applicable despite the fact that the record was left incomplete as a result of a constitutional error was Crane $v$ Kentucky. ${ }^{110}$ There, the defendant argued that his confession was involuntary and therefore inadmissible. The trial judge held a hearing, found the confession to be voluntary, and denied the motion to suppress the confession. At trial, the defendant attempted to introduce evidence "about the physical and psychological environment in which the confession was obtained." "111 The theory was that even if the confession was admissible, evidence that it was given under some duress would suggest that it should be given less weight by the jury.

The trial judge, however, granted the prosecution's motion to exclude any evidence of the circumstances under which the confession was given, on the view that such evidence bore only on the "voluntariness" of the confession, which had already been resolved. The Supreme Court reversed, finding that "the physical and psychological environment that yielded the confession can [] be of substantial relevance to the ultimate factual issue of the defendant's guilt or innocence,"112 and that a defendant's opportunity to present a defense "would be an empty one if the State were permitted to exclude competent, reliable evidence bearing on the credibility of a confession when such evidence is central to the defendant's claim of innocence."113

Nonetheless, citing Van Arsdall, the Court found that the error could be treated as harmless. ${ }^{114}$ The implication here is that like in Van Arsdall, the appellate court should imagine what would happen if the damaging potential of the testimony were fully realized. In this circumstance, full realization of the damaging potential of the testimony would mean that the trier of fact would accord no weight to the confession. Thus, the appellate court should engage in the usual harmless error analysis: disregard the tainted part of the record (here, the defendant's confession), and weigh the rest. In this sense, Crane foreshadowed the Court's subsequent decision in Fulminante that the introduction of a coerced confession could be treated as harmless.

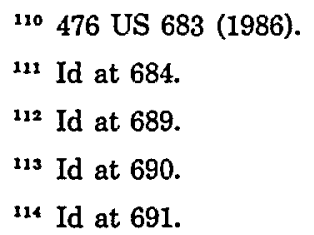


No such analysis applies where the government has intimidated a defense witness. The court must speculate as to the content and presentation of the suppressed evidence, not simply assess the effect of admitted evidence. Because the reviewing court will not know anything about the witness's composure or demeanor, nor even necessarily the precise content of his testimony, inquiring into the effects of the error is almost wholly speculative. It is impossible simply to strike out some part of the record and engage in the familiar harmless error analysis. Instead, the appellate court is left to guess what effect this evidence would have had on the jury.

\section{Requiring that the record be preserved.}

Further support for this position comes from Luce $v$ United States, ${ }^{115}$ where the Supreme Court ruled that in order to preserve an objection under Federal Rule of Evidence 609(a), a defendant must testify. The government charged Luce with a number of drug violations. In deciding whether to testify on his own behalf, the defendant asked for an in limine ruling ${ }^{116}$ that evidence of his prior drug conviction would not be admissible under Rule 609(a). ${ }^{117}$ The judge concluded that the specific evidentiary ruling would depend on the nature of the defendant's testimony. For example, if the defendant were only to testify about his attempt to flee from the arresting officers, then the prejudicial effect of the evidence might outweigh its probative value. The scales might tip the other way, however, if the defendant denied any previous involvement with drugs. ${ }^{118}$

The defendant elected not to testify and the jury returned guilty verdicts. The Sixth Circuit declared that it would not review a district court's in limine ruling where the defendant does not testify. ${ }^{119}$ The Supreme Court affirmed, noting that if appellate

118469 US 38 (1984).

118 A motion in limine is a "motion, whether used before or during trial, by which exclusion is sought of anticipated prejudicial evidence." Black's Law Dictionary 787 (West, 6th ed 1991).

117 Rule 609(a) provides that "[f]or the purpose of attacking the credibility of a witness, evidence that the witness has been convicted of a crime shall be admitted if elicited from him or established by public record during cross-examination but only if the crime (1) was punishable by death or imprisonment in excess of one year under the law under which the witness was convicted, and the court determines that the probative value of admitting this evidence outweighs its prejudicial effect to the defendant, or (2) involved dishonesty or false statement, regardless of the punishment." FRE 609(a), quoted in Luce, 469 US at $40 \mathrm{n} 1$.

118 Luce, 469 US at 40.

118 United States v Luce, 713 F2d 1236 (6th Cir 1983). 
courts reviewed in limine rulings absent the defendant's testimony, "almost any error would result in the windfall of automatic reversal; the appellate court could not logically term 'harmless' an error that presumptively kept the defendant from testifying." 120 The Court added that requiring "that a defendant testify in order to preserve Rule 609(a) claims will enable the reviewing court to determine the impact any erroneous impeachment may have had in light of the record as a whole ...."121

The theme here is that an appellate court cannot undertake harmless error analysis if it has to assess the prejudicial effect of an erroneous in limine ruling. This determination would require the appellate court to determine whether the ruling caused the defendant not to testify, and then figure out what harm thereby resulted. This type of analysis cannot work.

If the absence of the defendant's testimony makes harmless error analysis impossible, thereby creating a rule of per se reversal, the same should be true when the court faces an absence of testimony from a defense witness due to governmental intimidation. In either case, the court must have a complete record on which to base a harmless error analysis. Only where the record is complete, can an erroneous ruling be appealed in its "concrete factual context," ${ }^{122}$ without requiring judicial guesswork.

B. The Second Prong: Errors Affecting the Structural Integrity of the Trial

The cases suggest that a test requiring per se reversal only for errors whose harm escapes measurement would be partially underinclusive. "Harmless-error analysis [] presupposes a trial, at which the defendant, represented by counsel, may present evidence and argument before an impartial judge and jury."123 Therefore, where an error distorts the trial process itself so as to deny the defendant a fair opportunity to defend herself, per se reversal is required. ${ }^{124}$

The governing principle here is that what occurs in the process of investigating or gathering information about a crime has a less fundamental impact on the process of determining guilt than the structure of the criminal trial itself. Where the police obtain evidence without a warrant, or in violation of the Counsel Clause, or

\footnotetext{
${ }^{120}$ Luce, 469 US at 42.

121 Id.

122 Id at 43, quoting New Jersey $v$ Portash, 440 US 450, 462 (1979) (Powell concurring).

${ }^{123}$ Rose $v$ Clark, 478 US at 578 (footnote omitted).

124 Fulminante, $111 \mathrm{~S}$ Ct at 1265.
} 
even through coercion, the harm is less "structural" than when the state rigs the trial itself by denying adequate counsel to the defendant or subjecting him to a biased judge. An appellate court can set aside improperly admitted evidence and focus on the remaining, errorless, portions of the record. But a structural defect pervades the entire record.

Of course, most errors that transcend the criminal process and alter the structure of the trial also make it impossible to determine whether the error was harmless. To that extent, the two prongs of the test just described overlap. However, this may not be true for all errors. Some "structural" constitutional errors will never affect the jury's decision, and therefore will never cause harm. Nonetheless, the Supreme Court has still applied a rule of per se reversal in such cases.

For example, in McKaskle $v$ Wiggins, the Court invoked this conception of structural error, applying per se reversal to the denial of a defendant's right to self-representation. ${ }^{126}$ The Court found that a defendant's right to self-representation "plainly encompasses certain specific rights to have his voice heard. The pro se defendant must be allowed to control the organization and content of his own defense, to make motions, to argue points of law, to participate in voir dire, to question witnesses, and to address the court and the jury at appropriate points in the trial."126 Because of the structural import of this right, its denial may not be treated as harmless. "Since the right of self-representation is a right that when exercised usually increases the likelihood of a trial outcome unfavorable to the defendant, its denial is not amenable to 'harmless error' analysis. The right is either respected or denied; its deprivation cannot be harmless."127

A similar situation arises where a court finds evidence of racial discrimination in a grand jury selection. The issue came before the Supreme Court in Vasquez $v$ Hillery, ${ }^{128}$ in which the Court found that harmless error analysis does not apply to this constitutional error. ${ }^{129}$ Yet this sort of error, almost by definition, will cause no harm. In Vasquez, a tainted grand jury indicted, but an untainted petit jury determined that the defendant was guilty beyond a rea-

128465 US 168 (1984).

${ }^{128}$ Id at 174.

127 Id at $177 \mathrm{n} 8$.

128474 US 254 (1986). (1979).

129 Accord Cassell v Texas, 339 US 282 (1950); Rose v Mitchell, 443 US 545, 551-52 
sonable doubt. It would not appear possible that the constitutional error involved in choosing the grand jury could have had any effect on the petit jury's determination of guilt.

The Court, however, dismissed this argument, noting that the "overriding imperative to eliminate this systemic flaw in the charging process, as well as the difficulty of assessing its effect on any given defendant, requires our continued adherence to a rule of mandatory reversal." ${ }^{130}$ Here, the Court's concern is that the constitutional error tainted the structural integrity of the process for determining guilt or innocence in such a way that even if the result were not altered, a new trial was required.

Governmental intimidation of a defense witness shares a number of important characteristics with the structural errors in McKaskle and Vasquez. For example, intimidation of a defense witness is not the sort of error simply made in the presentation of the case to the jury. Instead, before the defendant presents his case, the range of available evidence has been restricted, and the course of the trial altered. This is true whether the governmental actor responsible for the intimidation is a judge, prosecutor, or police officer.

Additionally, when judges or prosecutors intimidate witnesses, they cause more serious systemic damage. Both judges and prosecutors are officers of the court, entrusted to administer justice fairly. Both the judge and the prosecutor are also the "symbol of the government's power to prosecute offenders."131 When a trial judge or prosecutor intimidates a witness, the trial is tainted in a way that resembles the situation in Vasquez. Thus, even if a court found that governmental witness intimidation failed to prejudice the defendant's case, per se reversal would still be required.

\section{ConcLusion}

Drawing the line between those errors subject to harmless error analysis and those that require per se reversal presents a complicated problem. On the one hand, the Court is appropriately concerned that requiring reversal and a new trial for every error, even the most trivial ones, would impose a tremendous burden on the

130 Vasquez, 474 US at 264. See also Rose $v$ Clark, 478 US at 578 (noting that "harmless error analysis presumably would not apply if a court directed a verdict for the prosecution in a criminal trial by jury"); Jackson v Virginia, 443 US 307, 320 n 14 (1979) ("Our cases have indicated that failure to instruct a jury on the necessity of proof of guilt beyond a reasonable doubt can never be harmless error.").

131 Morrison, 535 F2d at 228. 
criminal justice system. On the other hand, a broad application of harmless error doctrine renders useless many of the Constitution's grand protections of individual liberty. As one court put it, the worry is that "the purgatory of the harmless error doctrine [will] erode our sacred constitutional rights."132

In Fulminante, the Supreme Court made its most recent effort to strike this delicate balance, concluding that only "structural" errors require per se reversal. A reading of the Court's precedents suggests that a structural error is one for which (1) it is impossible to measure accurately the harm that results, or that (2) impugns the structural integrity of the trial. Governmental intimidation of a potential defense witness meets both of these requirements and, as a result, mandates per se reversal.

${ }^{132}$ United States $v$ Hammond, 598 F2d 1008, 1014 (5th Cir 1979). 